\title{
Extrahepatic Bile Duct Clear Cell Adenocarcinoma
}

National Cancer Institute

\section{Source}

National Cancer Institute. Extrahepatic Bile Duct Clear Cell Adenocarcinoma. NCI

Thesaurus. Code C5775.

A morphologic variant of extrahepatic bile duct adenocarcinoma characterized by the presence of malignant glandular epithelium composed of clear cells. 